Research Article

\title{
Neutrophil and Platelet to Lmphocyte Ratio in Ovarian Malignancy
}

\section{Rasio Netrofil dan Trombosit terhadap Limfosit pada Keganasan Ovarium}

\author{
Francesca Utama, Hermie Tendean, Bismarck J Laihad \\ Department of Obstetrics and Gynecology \\ Faculty of Medicine Universitas Sam Ratulangi/ \\ Prof. Dr. R.D. Kandou General Hospital \\ Manado
}

\begin{abstract}
Objective: To determine the sensitivity and specificity of neutrophil - lymphocyte ratio compared with platelet - lymphocyte ratio in predicting ovarian malignancies.

Methods: This was an observational analytic study with diagnostic test design on 37 ovarian tumor patients who were planned to perform laparotomy in Prof. Dr. R.D. Kandou Hospital Manado and network hospitals in Manado from March to May 2016. We took blood samples to assess the complete blood count.

Results: During the period, we obtained the mean age of 28.1 years old (range 18-71 years old). A total of 13 samples showed malignancy which the cystadenocarcinoma mucinosum $(27.0 \%)$ as the most common histopathological types. Sensitivity and specificity value of neutrophil - lymphocyte ratio were $92.3 \%$ and $95.8 \%$ with 2.47 as the cut-off point. Meanwhile, the sensitivity and specificity of platelet - lymphocyte ratio were $61.5 \%$ and $75.0 \%$ with 152.86 as cut-off point.

Conclusion: Both neutrophil - lymphocyte ratio and platelet lymphocyte ratio are associated with ovarian malignancy. The sensitivity and specificity of neutrophil - platelet ratio show better prediction for ovarian malignancies.

[Indones J Obstet Gynecol 2017; 5-1: 55-59]

Keywords: neutrophil - lymphocyte ratio, ovarian cancer, platelet lymphocyte ratio
\end{abstract}

\section{Abstrak \\ Abstrak}

Tujuan: Mengetahui sensitivitas dan spesifisitas rasio netrofil limfosit dibandingkan rasio trombosit - limfosit dalam memprediksi keganasan ovarium.

Metode: Penelitian ini merupakan penelitian observasional analitik dengan rancang uji diagnostik pada 37 penderita tumor ovarium yang direncanakan laparotomi di RSUP Prof. Dr. R.D. Kandou Manado dan rumah sakit jejaring di Manado pada bulan Maret sampai Mei 2016. Sampel diambil melalui darah vena untuk dilakukan pemeriksaan darah lengkap.

Hasil: Didapatkan rerata usia pasien adalah 28,1 tahun (rentang 18 71 tahun). Sebanyak 13 sampel mengalami keganasan dengan jenis histopatologi terbanyak adalah kistadenokarsinoma musinosum (27,0\%). Nilai sensitivitas dan spesifisitas rasio netrofil - limfosit adalah $92,3 \%$ dan $95,8 \%$ dengan titik potong 2,47 dan rasio trombosit - limfosit adalah $61,5 \%$ dan $75,0 \%$ dengan titik potong 152,86 .

Kesimpulan: Rasio netrofil - limfosit dan rasio trombosit - limfosit berhubungan dengan keganasan ovarium. Sensitivitas dan spesifisitas rasio netrofil - trombosit menunjukkan hasil yang lebih baik dalam memprediksi keganasan ovarium.

[Maj Obstet Ginekol Indones 2017; 5-1: 55-59]

Kata kunci: kanker ovarium, rasio netrofil - limfosit, rasio trombosit limfosit

\section{INTRODUCTION}

Incidence of epithelial ovarian cancer is around 3\% of all cancers in women worldwide and it ranks the third among all gynecological cancers. In 2002, epithelial ovarian cancer contributed to more than 125,000 deaths each year of gynecological cancer. ${ }^{1}$ Although there has been improvement in the technique of surgery and chemotherapy, the prognosis of epithelial ovarian cancer patients was still poor with 5 -year survival rate of $40 \%$. It was because most of patients generally came at advanced stage. ${ }^{2,3}$

Recent studies stated that there was correlation between genetic transformation causing malignancy and activation of cancer inflammation reaction. ${ }^{3}$ There were many factors that involved in angiogenesis process correlating to ovarian cancer, such as inflammatory marker or types of blood cell. Increased absolute neutrophil, platelet, and lymphocyte count or neutrophil - lymphocyte and platelet - lymphocyte ratio had been reported as one of prognostic factors in ovarian cancer. The inflammatory response effects on tumor progression by activating the inflammatory cytokines that induce cellular DNA damage, inhibit apoptosis, and trigger the process of angiogenesis around tumor. This response causes the abnormal growth, progression, and metastases of tumor. ${ }^{4,5}$ Therefore, this study aims to determine the 
sensitivity and specificity of neutrophil lymphocyte ratio compared with platelet lymphocyte ratio in predicting ovarian malignancies

\section{METHODS}

This was an observational analytic study with diagnostic test design. This study was conducted in the Prof. Dr. R.D. Kandou Hospital Manado and network hospitals in Manado from March to May 2016. The inclusion criteria were all patients with ovarian tumors planned to perform laparotomy in Prof. Dr. R.D. Kandou Hospital Manado and network hospitals in Manado. Apart from that, the patients did not show any other malignancies. The exclusion criteria were patients with other disease that influenced significant amount of neutrophil, platelet, lymphocyte and or leukocyte, such as cardiovascular disease, viral infection, autoimmune disease, diabetes mellitus, blood disease. We excluded the patients who did not show the ovarium tumor as the primary source. We took intravenous blood sample to assess the complete blood count so that we could analyze neutrophil lymphocyte ratio and platelet - lymphocyte ratio. Variable of neutrophil - lymphocyte and platelet lymphocyte ratio was described in the cross tabulated table paired with histopathological result. The analysis of Receiver Operating Characteristic (ROC) curve was used to calculate the sensitivity and specificity of neutrophil lymphocyte and platelet - lymphocyte ratio to histopathology examination as the gold standard of diagnosis. We analyzed through SPSS and $p$ value of 0.05 was considered statistically significant.

\section{RESULTS}

We got 37 ovarian tumor patients who underwent surgery in Prof. Dr. R.D. Kandou Hospital Manado and network hospitals in Manado. Table 1 showed the characteristics of subjects. The mean age of patients was 40.4 (range 18-71) years old. We found 20-39 years old as the most prevalent of ovarian tumor patients in this study (40.5\%). Most of subjects had ever delivery once to twice $(43.2 \%)$ and they had normal body mass index (BMI) $(64.8 \%)$.

Table 2. Characteristics of Histopathology on Ovarian Tumor

\begin{tabular}{lcc}
\hline \multicolumn{1}{c}{ Histopathology Profile } & N & \% \\
\hline Benign & 5 & 13.5 \\
Cystadenoma Serosum & 9 & 24.3 \\
Cystadenoma Mucinosum & 3 & 8.1 \\
Dermoid cyst & 7 & 18.9 \\
Hemorrhagic Cyst & & \\
Malignant & 3 & 8.1 \\
Cystadenocarsinoma Serosum & 10 & 27.0 \\
Cystadenocarsinoma Mucinosum &
\end{tabular}

Of the 37 cases, we found the malignant cyst adenocarcinoma mucinosum as many as 10 patients $(27.0 \%)$ and cystadenocarcinoma serosum as many as 3 patients $(8.1 \%)$. While most were benign ovarian tumor of cystadenoma mucinosum (24.3\%), cystadenoma serosum (13.5\%), hemorrhagic ovarian cysts $(18.9 \%)$, and the least number of dermoid cyst (8.1\%).

Table 1. The Characteristics of Subjects

\begin{tabular}{lccccc}
\hline \hline & Characteristics & N & \% & Range (min-max) & Mean \\
\hline Age & $<20$ & 3 & 8.1 & & 18.3 \\
& $20-39$ & 15 & 40.5 & $18-71$ & 28.1 \\
& $40-59$ & 12 & 32.4 & & 47.4 \\
& $\geq 60$ & 7 & 18.9 & & 64.3 \\
\multirow{4}{*}{ Parity } & 0 & 10 & 27.0 & $0-5$ & 0 \\
& $1-2$ & 16 & 43.2 & & 1.6 \\
& $3-5$ & 11 & 29.7 & & 3.4 \\
BMI & $\leq 18$ & 3 & 8.1 & $16.4-34.5$ & 15.8 \\
& $18-24$ & 24 & 64.8 & & 21.4 \\
& $\geq 25$ & 10 & 27.0 & & 30.6 \\
\hline \hline
\end{tabular}




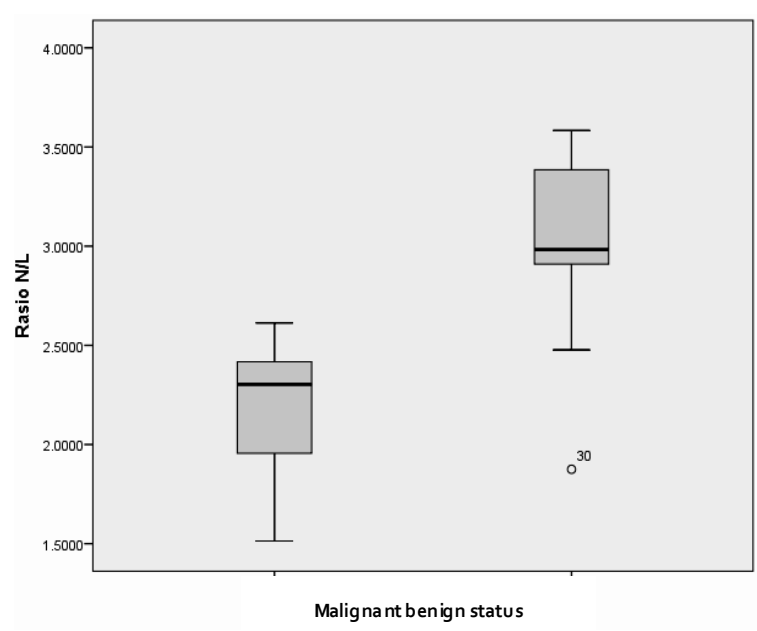

Figure 1. Distribution of NLR to Tumor Stage

In the Shapiro-Wilk normality test due to small sample size, we indicated that the data of both neutrophil - lymphocyte ratio and platelet lymphocyte ratio in benign and malignant ovarian tumors were normally distributed ( $p>0.05)$. Thus, we processed the test into parametric test. The result of $\mathrm{T}$ test showed that there were significant differences in neutrophil - lymphocyte also platelet - lymphocyte ratio between patients with benign and malignant ovarian tumors $(\mathrm{p}<0.05)$. It meant that the ratio of them was associated with ovarian malignancy.

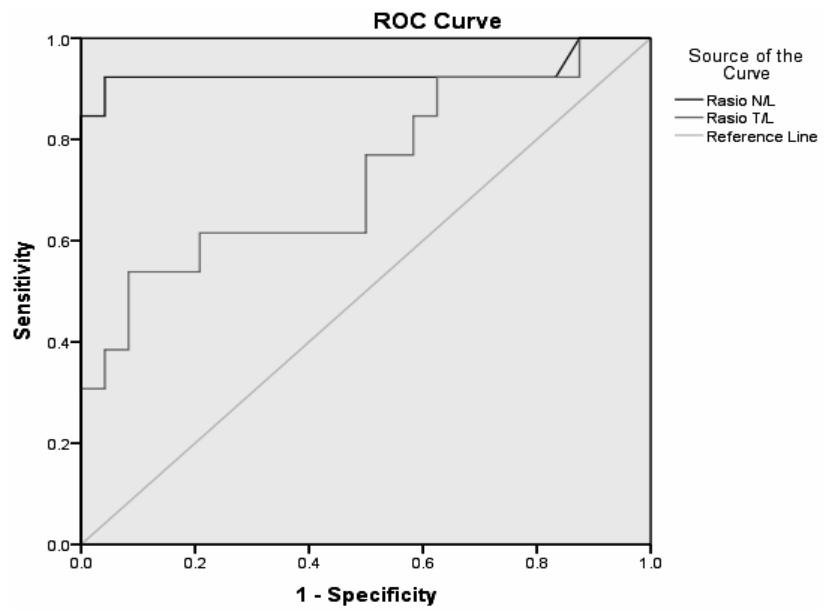

Figure 3. ROC Curver

Of the ROC curve, we obtained area under the curve (AUC) value of neutrophil - lymphocyte ratio was $93.1 \%(\mathrm{p}<0.05$; 95\% CI 80.6-100.0\%). Meanwhile, AUC value of platelet - lymphocyte ratio was

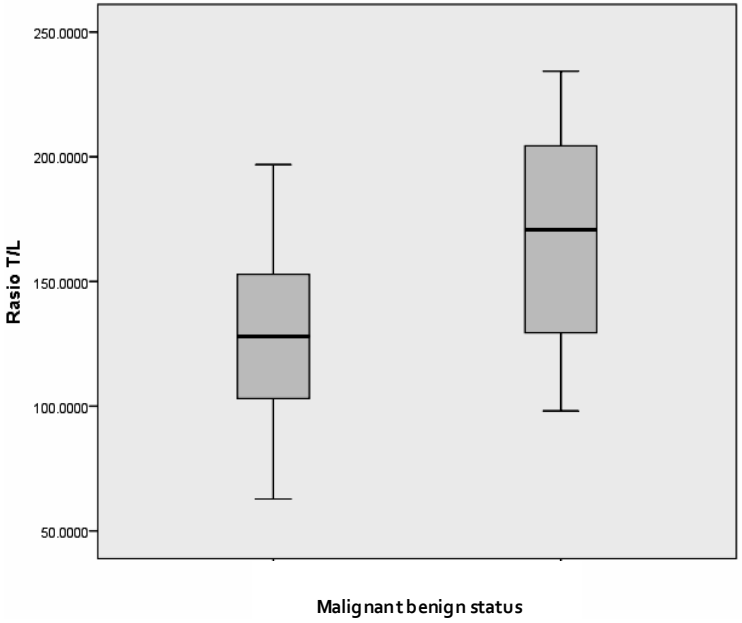

Figure 2. Distribution of PLR to Tumor Stage

$60.5 \%$ ( $\mathrm{p}=0.022 ; 95 \%$ CI 55.0-91.1\%). The analysis of ROC stated that the optimal sensitivity and specificity of neutrophil - lymphocyte ratio was $92.3 \%$ and $95.8 \%$ with a cut-off point on the value of 2.47. While, the value of optimal sensitivity and specificity of platelet - lymphocyte ratio was $61.5 \%$ and $75.0 \%$ with 152.86 as the cut-off point. Both ratios were confirmed with histopathology results.

\section{DISCUSSION}

Progression and metastases of cancer consist of cascade steps that involve interaction among tumor microenvironment, including factors that contribute to angiogenesis and inflammation. The capacity of tumor cells to invade, get vascularization and metastasis is initiated by a signal from the primary tumor of microenvironment, blood vessel, and secondary location of tumor.6,7 The inflammatory response has correlation with tumor progression, such as angiogenesis and tumor invasion through upregulation of cytokines. In response to the various forms of inflammation, tumor microenvironment containing innate immune cells (macrophage, neutrophil, mast cell, dendritic cell, and natural killer cell) and adaptive immune cells (lymphocyte $\mathrm{T}$ and $\mathrm{B}$ ) has associated with the production of cytokines and chemokines and they act in autocrine and paracrine communication to organize and establish the growth and progression tumor. 8,9 Systemic inflammation associated with the release of several pro-inflammatory mediators, such as IL-1, IL-3 and IL-6 is believed to be able to stimulate proliferation of megacaryocyte and 
platelet activation that will produce proangiogenic factor. The proangiogenic factor is essential for tumor growth. In addition, a number of immunological mediators, such as IL-10 and TGF- $\beta$ are released; they will cause significant immunosuppressive effects in order to disrupt lymphocyte function and reduce the number of lymphocyte.7,8,10-12 Ovarian cancer is associated with inflammation that triggers activation of transcription factors, such as hypoxic-inducing factor (HIF), signal transducer, activator of transcription 3 (Stat3), and nuclear factor B (NFB). These transcription factors result in the production of chemokines, cytokines and prostaglandins, which not only produce inflammatory cells, but also stimulate angiogenesis and cell proliferation. Anti-inflammatory systemic mediator releases inhibitors, including IL-10 and TGF- $\beta$, which will suppress the immune system and reduce the function of lymphocytes. ${ }^{13-15}$ Lymphopenia process has prognostic factor which is associated with poor outcome of different kind of cancers, such as renal, pancreatic, and ovarium. ${ }^{7,15-18}$

In this study, most subjects were 20-39 years old (40.5\%). Aziz MF, et al. obtained the ovarian tumor patients were 20-65 years old; whereas, this range of age in population was the most common for ovarian tumor. ${ }^{19}$

The result of $\mathrm{T}$ test showed that both neutrophil-lymphocyte and platelet - lymphocyte ratio had association with malignant ovarian tumor $(p<0.05)$. Yildirim $M$, et al. stated that there was strong correlation between neutrophil lymphocyte ratio and the process of cancer, including cancer staging, prognosis and response to therapy. The ratio of neutrophil - lymphocyte and neutrophil - lymphocyte is a marker of inflammation that is effective to predict preoperative ovarian cancer. Both of these markers are cheap, effective, and generally accepted in predicting malignancy of ovarian tumor. ${ }^{6}$ The inflammatory tumor microenvironment plays a role in cancer growth. Inflammation can increase the mutation rate and improve the proliferation of mutated cell. Inflammation is related to cancer each other. The damage of DNA in cancer cells can cause more severe inflammation and promote cancer. Some pro-inflammatory gene products have been identified of having an important role in the suppression of apoptosis, proliferation, angiogenesis, invasion, and metastases.
Raungkaewmanee S, et al. in 2012 conducted study on platelet - lymphocyte ratio as a prognostic factor in epithelial ovarian cancer. Several previous studies reported an increase in absolute neutrophil and platelet, the decrease of lymphocyte count in the incidence of cancer. ${ }^{4}$ Furthermore, in a study conducted by Asher V, et al. in 2011, cancer patients increasing platelet - lymphocyte ratio had worse prognosis. The inflammatory response affects tumor progression by activating the inflammatory cytokines that induce cellular DNA damage, inhibiting apoptosis, and triggering the process of angiogenesis around tumor. This causes the abnormal growth of tumor, progression, and metastases. ${ }^{5}$

In this study, the ROC curve showed that the optimal sensitivity and specificity of neutrophil lymphocyte ratio was $92.3 \%$ and $95.8 \%$ with a cut-off point on the value of 2.47 . While, the optimal sensitivity and specificity of platelet lymphocyte ratio was $61.5 \%$ and $75.0 \%$ with a cutoff point on the value 152.86 . This result had been compared to histopathology results. We could conclude that the ratio of neutrophil - lymphocyte and platelet - lymphocyte had good value for predicting ovarian malignancies. Neutrophil lymphocyte ratio had better marker compared with platelet - lymphocytes ratio.

According to Yidrim, et al. in 2014, neutrophil lymphocyte and platelet - lymphocyte ratio might be used in combination with Ca-125 because Ca-125 was believed to have high sensitivity in differentiating benign and malignant ovarian tumor. The Ca-125 as screening method remains the most important; however, the neutrophil lymphocyte ratio and the number of neutrophil can be used in single or combination with Ca-125 to detect early stage of ovarian tumor. ${ }^{6}$

\section{CONCLUSION}

Both neutrophil - lymphocyte ratio and platelet lymphocyte ratio are associated with ovarian malignancy. The sensitivity and specificity of neutrophil - platelet ratio shower better prediction for ovarian malignancies. Both of these markers are cheap, effective, and generally accepted in predicting malignancy of ovarian tumor preoperatively. 


\section{REFFERENCES}

1. Jemal A, Siegel R, Xu J, et al. Cancer Statistics, 2010. CA Cancer J Clin. 2010; 60: 277-300.

2. Fader AN, Rose PG. Role of surgery in ovarian carcinoma. J Clin Oncol. 2007; 25: 2873-83.

3. Guthrie GJK, Charles KA, Roxburgh C. The systemic inflammation based neutrophil - lymphocyte ratio: Experience in patient in cancer. Critical Reviews in Oncology/Hematology. 2013; 88: 218-30.

4. Raungkaewmanee S. Platelet to lymphocyte ratio as a prognostic factor for epithelial ovarian cancer. J Gynecol Oncol. 2012; 23(4): 265-73.

5. Asher V, Lee J, Innamaa A. Preoperative platelet lymphocyte ratio as an independent prognostic marker in ovarian cancer. Clin Transl Oncol. 2011; 13: 499-503.

6. Yildirim M, Cendek B, Avsar A. Differentiation between benign and malignant ovarian masses in the preoperative period using neutrophil-to-lymphocyte and platelet-tolymphocyte ratios. Mol Clin Oncol. 2015; 3: 317-21.

7. Zhou X. Prognostic Value of PLR in Various Cancers: A MetaAnalysis. PLOS One. 2014; 9(6): 1-8.

8. Grivenikov S I, Greten F, Karin M. Immunity, Inflammation and Cancer. Cell. 2010; 883-99.

9. Hanahan D, Weinberg WA. Hallmark of Cancer: The Next Generation. Cell. 2014; 144: 755-821.

10. Mantovani A, Balkwill F. Cancer-Related Inflammation. Nature. 2008; 454: 426-43.

11. MacDonald N. Chronic inflammatory states: their relationship to cancer prognosis and symptoms. J R Coll Physicians Edinb. 2011; 41: 246-53.
12. Kim H, Choi H, Lee M. Systemic Inflammatory Response Markers and Ca-125 Levels in Ovarian Clear Cell Carcinoma: A Two Center Cohort Study. Cancer Res. Treat. 2016; 48(1): 250-8.

13. Oh J, Choi M, Park H. Preoperative Thrombocytosis Is an Independent Poor Prognostic Factor in Patients with Epithelial Ovarian Cancer. Clin Exp Thromb Hemost. 2014; 1(1): 17-21.

14. Bambace NM, Holmes E. The platelet contribution to cancer progression. J Thrombosis Haemostasis. 2011; 9: 237-49.

15. Egan K, Crowley D, Smyth P. Platelet Adhesion and Degranulation Induce Pro-Survival and Pro-Angiogenic Signalling in Ovarian Cancer Cells. Plos One. 2011; 6: 1.

16. Bakacak M, Serin S, Ercan O. Utility of Preoperative neutrophil-to-lymphocyte and platelet-to-lymphocyte ratios to distinguish malignant from benign ovarian masses. J Turk Ger Gynecol Assoc. 2015; 16(0): 1049.

17. Lee Y,Choi C, Kim H. Pretreatment Neutrophil: Lymphocyte Ratio as a Prognostic Factor in Cervical Carcinoma. Anticancer Research. 2012; 32: 1555-62.

18. Auersperg N, Wong AS, Choi KC, et al. Ovarian surface epithelium: Biology, endocrinology, and pathology. Endocr Rev. 2001; 22(2): 25588.

19. Aziz MF, Andrijono, Saifuddin AB. Buku acuan Nasional Onkologi Ginekologi. Yayasan Bina Pustaka Sarwono Prawirohardjo. Departemen Obstetri dan Ginekologi Fakultas Kedokteran Universitas Indonesia. Ed pertama. 2006; 469-527. 